\title{
The role of mean platelet volume as a predictor of postoperative shunt occlusion in children who underwent modified blalock-taussig shunt surgery
}

\author{
ModifiyeBlalock-Taussig Şant Operasyonu Geçiren Çocuklarda Erken Şant Oklüzyonu \\ Öngörmede Ortalama Trombosit Hacminin Rolü
}

\author{
Ulaş Kumbasar*,Hatice Hale Temel*,Onur Saydam **,Hasan Tolga Çelik* "Murat Güvener",Rıza Doğan*, \\ Metin Demircin*,ilhan Paşaoğlu*
}

\author{
*Hacettepe Üniversitesi Tıp Fakültesi,Göğüs-Kalp ve Damar Cerrahisi Kliniği \\ **izmir Tepecik Eğitim ve Araştırma Hastanesi,Kalp ve Damar Cerrahisi Kliniği \\ ***Hacettepe Üniversitesi Tıp Fakültesi, Çocuk Sağlığı ve Hastalıklar AD, Yenidoğan BD
}

\begin{abstract}
Purpose:Backgrounds:The modified Blalock-Taussig shunt (mBTS) is a palliative procedure which is often performed to maintain additional pulmonary blood flow. Postoperative shunt patency is critical in order to provide adequate systemic oxygenation. Mean platelet volume (MPV) correlates with platelet function and there is a possible correlation between an increase in MPV and the risk of thrombosis.

Aim:The aim of this study was to determine the role of MPV as a potential risk factor in postoperative early shunt occlusion in children underwent mBTS surgery.

Materials and methods:This study was carried out with 1117 women. Body Mass Index was calculated by the formula: body weight/height $\left(\mathrm{kg} / \mathrm{m}^{2}\right)$, body composition was assessed by bioelectrical impedance analysis; waist circumference was measured and waist/height ratio was calculated. For determining the physical activity status of individuals, individual physical activity records were investigated. In addition, the variables associated with obesity were assessed in relation to BMI.

Results:In the majority of cases the operation was performed via thoracotomy $(89.7 \%)$. The shunt was constructed between the subclavian artery and pulmonary artery in 187 cases. In the remaining 8 patients the shunt was connected to the innominate artery. Twenty-three patients $(11.8 \%)$ experienced early shunt occlusion. Preoperative MPV levels were 8.2 (6.2-14.0) in no occlusion group and 8.3 (6.9-10.7) in occlusion group. Neither MPV nor other variables showed a statistically significant association with early shunt occlusion

Conclusion:Despite some other studies demonstrating an association between high MPV levels and thrombosis, we could not find any statistically significant association between MPV and early shunt occlusion.
\end{abstract}

Pam Med J 2017;10(3):258-263

Keywords:Mean platelet volume, Modified Blalock-Taussig shunt, Occlusion.

\section{Özet}

Amaç:Modifiye Blalock-Taussig (mBTS) şantı pulmoner kan akımını arttırmak amacı ile yapılan palyatif bir prosedürdür.Yeterli sistemik oksijenasyonu sağlayabilmek için şant açıklığının kritik önemi vardır. Ortalama trombosit hacmi (OTH), trombosit fonksiyonu ile ilişkilidir. Bu ilişki aynı zamanda artmış OTH ve tromboz riski arasında da olduğu düşünülmektedir.

Çalışmamızın amacı mBTS operasyonu geçiren çocuklarda OTH'nin potansiyel bir risk faktörü olarak erken şant oklüzyonundaki rolünü belirlemektedir.

Gereç ve yöntem:Çalışma Planı:Retrospektif kesitsel çalışma. Bu vaka kontrol çalışması Ocak 2006 ve Mart 2013 tarihleri arasında tıbbi kayıtlardan derlenmiştir. Toplamda 195 hasta çalışmaya dahil edilmiştir. Fonksiyonel tek ventrikül, Konoventriküler septum malalignment'i olan veya olmayan pulmoner atrezi ve pulmoner stenoz tanısı olan çocuklar dahil edilmiştir.

Bulgular:Operasyonların büyük çoğunluğu torakotomi ile yapılmıştır (\%89,7). 187 hastada şant subklavyen arter ve pulmoner arter arasında oluşturulmuştur. Kalan 8 hastada ise şant innominate arter ve pulmoner arter arasında oluşturulmuştur.23 hastada $(\% 11,8)$ erken şant oklüzyonu izlenmiştir. Preoperatif OTH oklüzyon olmayan grupta 8.2 (6.2-14.0) iken oklüzyon izlenen grupta bu değer 8.3 (6.9-10.7) olarak izlenmiştir.OTH ve diğer değişkenler erken şant oklüzyonu izlenen ve izlenmeyen gruplar arasında istatiksel olarak anlamlı fark göstermemiştir.

Sonuç:OTH ve trombozis arasındaki ilişkiyi gösteren yayınlardan farklı olarak çalışmamızda OTH ve erken şant oklüzyonu arasında istatiksel olarak anlamlı bir ilişki bulunamamıştır.

Pam Tip Derg 2017;10(3):258-263

Anahtar sözcükler:Ortalama trombosit hacmi, Modifiye Blalock-Taussig Şant, Oklüzyon.

\author{
Ulaş Kumbasar \\ Yazışma Adresi:Hacettepe Üniversitesi Tıp Fakültesi,Göğüs-Kalp ve Damar Cerrahisi Kliniği \\ e-mail:ulaskumbasar@gmail.com
}




\section{Introduction}

The modified Blalock-Taussig shunt (mBTS) is a first-line palliative procedure in congenital heart surgery that is often performed for rightsided obstructive cardiac defects to maintain additional pulmonary blood flow. A graft is placed between the systemic and pulmonary arterial circulations and systemic blood flow is redirected into the pulmonary circulation. Postoperative shunt patency is critical, particularly in children with shunt-dependent circulation, to maintain adequate systemic oxygenation. Thus, prevention, recognition and treatment of acute thrombotic shunt occlusion are crucial. However, clinical variables that can be predictive of postoperative shunt occlusion are vague [1-6]. Platelets have a pivotal role in both thrombosis and inflammation that are highly related with each other. Mean platelet volume (MPV), which is the quantity of the average size of platelets encountered in the blood, correlates with platelet function and activation. Larger platelets contain more granules and produce greater amounts of vasoactive and prothrombotic factors, such as thromboxane A2, serotonin, and adenosine triphosphate and finally, they express a greater number of adhesion molecules, such as P-selectin and glycoprotein IIb/llla. [7,8]. Besides, elevated MPV has been associated with cardiovascular and cerebrovascular diseases, which suggests a correlation between an increase in MPV and the risk of thrombosis $[9,10]$. The aim of this retrospective study was to determine the role of MPV as a potential risk factor in postoperative early shunt occlusion in children underwent mBTS surgery.

\section{Material and Methods}

After Institutional Research Committee approval, a retrospective study chart was performed on all patients who underwent $\mathrm{mBTS}$ between January 2006 and March 2013. Data were collected from intensive care observation charts and patient records. In total there were 228 shunts undertaken during this period. Patients undergoing cardiopulmonary bypass (CPB) support for hemodynamic instability and/or another surgical procedure including the division of a patent ductus arteriosus concurrently with the mBTS were excluded and 195 patients were enrolled into the study.

All patients received a heparin bolus of 100 units $/ \mathrm{kg}$ intraoperatively before shunt placement. Gore-Tex polytetrafluoroethylene (PTFE) grafts (W.L. Gore \& Assoc, Flagstaff,
AZ) were used for all patients. All patients were mechanically ventilated for a minimum of 24 hours postoperatively. Heparin infusion was commenced at $10 \mathrm{units} / \mathrm{kg} / \mathrm{hr}$ and adjusted according to the patients' activated partial thromboplastin time (APTT) during the postoperative period. Consequently, all patients received a daily oral dose of $10 \mathrm{mg} /$ $\mathrm{kg}$ aspirin. Patients who had hemodynamic instability (low cardiac output or persistent hypotension) and/or cardiac resuscitation during the early postoperative period were excluded from the study. Shunt occlusion was defined by any one of the following: [1] absence of a murmur by clinical examination in conjunction with increasing cyanosis with supportive evidence of narrowing or thrombosis of a shunt or of stenosis at the shunt insertion site; [2] absence of flow on echo Doppler, angiography, magnetic resonance imaging, or computerized tomography; [3] need for an urgent repeated shunt as a result of prohibitive cyanosis. Early shunt occlusion was defined as complete occlusion during the hospitalization period. Blood samples for MPV, hemoglobin $(\mathrm{Hb})$, hematocrit $(\mathrm{Htc})$, white blood cell (WBC), red cell distribution width (RDW), platelet count and activated partial thromboplastin time (aPTT) were obtained preoperatively and at postoperative $4^{\text {th }}$ hour, respectively. Statistical analyses were performed by IBM SPSS for Windows Version 21.0 statistical package (Chicago, IL, USA). Continuous variables were presented as mean \pm standard deviation or median (minimum-maximum). Categorical variables were summarized as frequencies and percentages. Normality of the continuous variables was evaluated by Shapiro Wilks test. Differences between the two groups according to continuous variables were determined by independent samples $t$ test or Mann Whitney $\mathrm{U}$ test as appropriate. Categorical variables were compared by Pearson chi square or Fisher's exact test. A p value less than 0.05 was considered as significant.

\section{Results}

A total of 195 patients, 102 male and 93 female, were enrolled into the study. Median age of the children was 80 days old (range 0 day-15 years) and their median weight was $3.8 \mathrm{~kg}$ (range 1.5-46 kg). Eighty-five patients $(43.5 \%)$ were neonates, defined as less than 30 days of age. Diagnoses included pulmonary atresia or stenosis with malalignment of the conoventricular septum $(n=111)$, pulmonary atresia or stenosis without malalignment of the conoventricular septum $(n=48)$ and functional 
single ventricle $(n=36)$. In the majority of cases the operation was performed via thoracotomy $(89.7 \%)$. The shunt was constructed between the subclavian artery and pulmonary artery in 187 cases. In the remaining 8 patients the shunt was connected to the innominate artery. The shunt was placed in the right side in 40 patients whereas in 135 patients it was placed in the left side. In 20 patients shunt was performed through a median sternotomy.

Table1. Patient Characteristics.

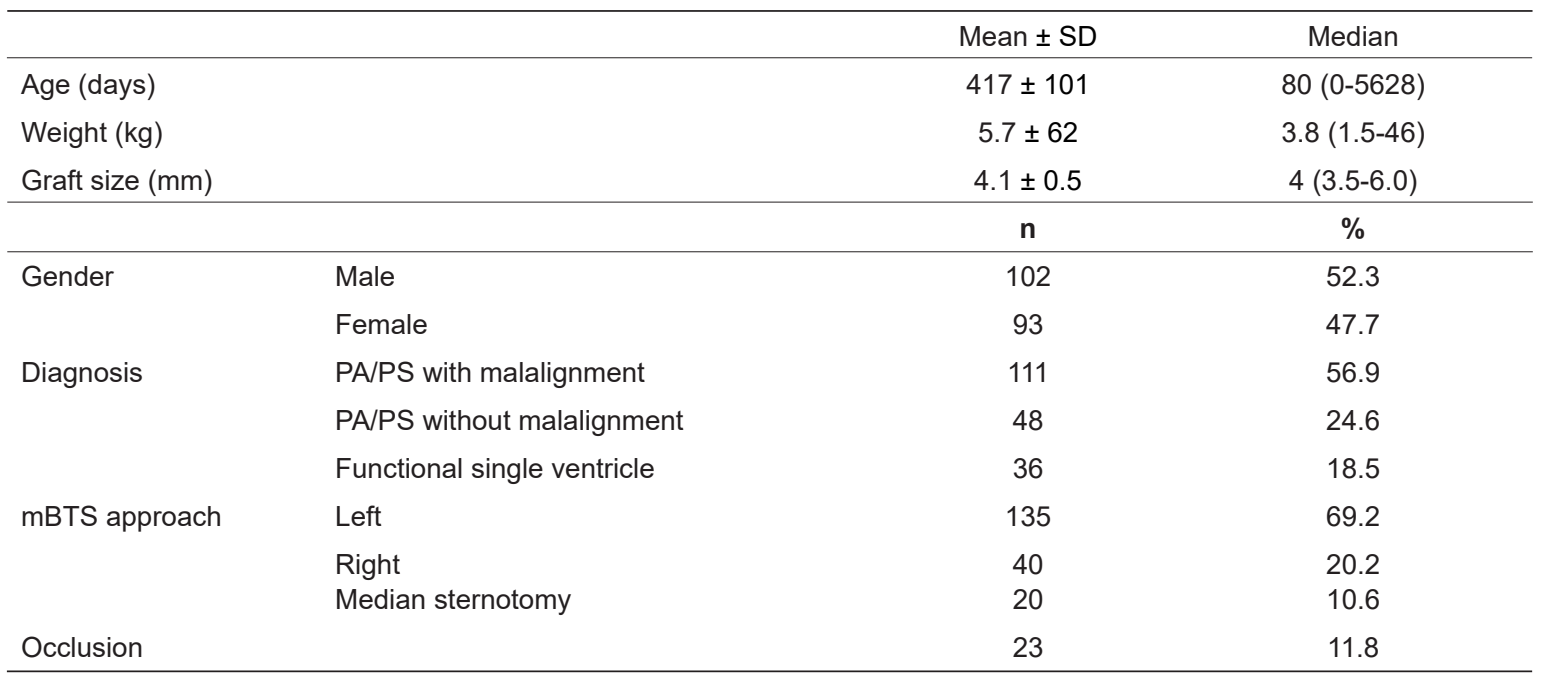

PA = Pulmonary atresia; PS = Pulmonary stenosis; mBTS = Modified Blalock Taussig Shunt.

Univariate analyses of all collected perioperative laboratory variables between patients who had early shunt occlusion and patients who did not are shown in Table II. Neither MPV nor other variables mentioned above showed a statistically significant association with early shunt occlusion. Mean target pulmonary artery diameter was similar between the groups (4.05 $\mathrm{mm}$ (range 2.5-5) in the occlusion group versus $4.55 \mathrm{~mm}$ (range 2,5 9 ) in the non-occlusion group; $p=0.426$ ). Median Gore-Tex PTFE graft size for both groups were $4 \mathrm{~mm}$ (range 3.5-6 mm). Similarly, cardiac diagnosis was not considered to be significantly associated with shunt occlusion, either (Table III).

\section{Discussion}

In today's cardiac surgery mBTSs continue to have an important role. Thrombotic occlusion of a mBTS is a devastating event for patients especially who are shunt dependent. In this study, we aimed to determine the role of MPV as a predictive factor in early shunt occlusion. Even with the use of appropriate anticoagulation therapy, thrombotic occlusion of a mBTS is frequent. A large international multicenter study with a total of 1004 patients showed a shunt
The postoperative transfusion of red blood cell (RBC) levels $(\mathrm{ml} / \mathrm{kg})$ were greater in the occlusion group versus the no-occlusion group but did not reach statistical significance $(11 \pm 7$ versus $10 \pm 9 ; p=0.21)$. Twenty-three patients $(11.8 \%)$ experienced early shunt occlusion. Nine of the 23 occlusion patients $(39.1 \%)$ died during their hospitalization. Table I summarizes the demographic characteristics of the patients. occlusion rate of $12 \%$ [11]. Gedicke et al. also noted an $11.8 \%$ shunt occlusion rate in their recent study with 76 patients [12]. Our rate of shunt occlusion was also within these limits. Clinical predictors leading to shunt occlusion remains unclear. Some investigators showed that younger age and smaller shunt size were associated with shunt failure $[1,2,4,12]$. Al Jubair et al and Guzetta et al. reported that the size of the pulmonary artery being shunted had a significant impact in predicting shunt occlusion [13,14]. Moreover, Odim et al. showed that the thoracotomy approach and male gender increased the risk of shunt occlusion [15]. Recently, Gedicke et al. identifies high preoperative hemoglobin, a weight less than $3 \mathrm{~kg}$ at operation, and the presence of a patent duct as significant risk factors for shunt blockage in the acute postoperative period [12]. In another study, Sahoo et al. analyzed the role of hyperviscosity and showed that lowering the hematocrit levels resulted in improved shunt patency in the postoperative period [16]. Surprisingly, target pulmonary artery diameter, shunt size, hemoglobin and hematocrit levels all showed a nonsignificant trend in our analysis. Recent evidence supports the presence of a close relationship between 
Table 2. Perioperative Variables

\begin{tabular}{ccc}
\hline Laboratory Value & $\begin{array}{c}\text { No occlusion } \\
(n=172)\end{array}$ & $\begin{array}{c}\text { Occlusion } \\
(n=23)\end{array}$
\end{tabular}

MPV (fL)

$\begin{array}{lccc}\text { Preoperative } & 8.2(6.2-14.0) & 8.3(6.9-10.7) & 0.386 \\ \text { Postoperative } 4^{\text {th }} \text { hour } & 7.9 \pm 0.8 & 7.8 \pm 0.8 & 0.411\end{array}$

$\mathrm{Hb}(\mathrm{g} / \mathrm{dl})$

$\begin{array}{lccc}\text { Preoperative } & 14.8 \pm 3.2 & 15.5 \pm 2.9 & 0.297 \\ \text { Postoperative } 4^{\text {th }} \mathrm{h} . & 12.9 \pm 2.7 & 13.4 \pm 3.8 & 0.449\end{array}$

Htc (\%)

\begin{tabular}{|c|c|c|c|}
\hline Preoperative & $44.7 \pm 9.4$ & $47.2 \pm 8.9$ & 0.224 \\
\hline Postoperative $4^{\text {th }} \mathrm{h}$. & $38.5 \pm 8.2$ & $41.0 \pm 11.0$ & 0.198 \\
\hline
\end{tabular}

WBC $\left(\times 10^{9} / L\right)$

Preoperative

$12.7 \pm 4.2$

$13.7 \pm 6.7$

0.209

Postoperative $4^{\text {th }} \mathrm{h}$.

$11.0(5.6-33.3)$

$14.3(6.4-39.5)$

0.237

$\operatorname{PLT}(x 10 \%)$

$\begin{array}{lccc}\text { Preoperative } & 261.4 \pm 13.8 & 256.7 \pm 12.7 & 0.868 \\ \text { Postoperative } 4^{\text {th }} \mathrm{h} . & 210.7 \pm 11.7 & 224.1 \pm 9.8 & 0.584\end{array}$

$\operatorname{RDW}(\%)$

$\begin{array}{lccc}\text { Preoperative } & 17.8(12.6-33.4) & 19.0(14.4-33.6) & 0.173 \\ \text { Postoperative } 4^{\text {th }} \mathrm{h} . & 17.9(12.1-32.7) & 18.5(14.9-33.5) & 0.149 \\ \text { aPTT time (second) } & 38 \pm 7.1 & 36 \pm 6.5 & 0.211 \\ \text { Preoperative } & 81 \pm 9.2 & 79 \pm 8.1 & 0.422 \\ \text { Postoperative } 4^{\text {th }} \mathrm{h} . & \end{array}$

MPV: Mean Platelet Volume; Hb: Hemoglobin; Htc: Hematocrit; WBC: White Blood Cell; PLT: Platelet; RDW: Red Cell Distribution Width, aPTT: Activated partial thromboplastin time.

Table 3. Comparison of Diagnosis

\begin{tabular}{lccccc}
\hline & \multicolumn{2}{c}{ No occlusion } & \multicolumn{2}{c}{ Occlusion } & p Value \\
\hline Diagnosis & $\mathrm{n}$ & $\%$ & $\mathrm{n}$ & $\%$ & \\
PA/PS with malalignment & 99 & 89.2 & 12 & 10.8 & 0.872 \\
PA/PS without malalignment & 42 & 87.5 & 6 & 12.5 & 13.9 \\
Functional single ventricle & 31 & 86.1 & 5 & \\
\hline
\end{tabular}

$\mathrm{PA}=$ Pulmonary atresia; $\mathrm{PS}=$ Pulmonary stenosis 
inflammation and thrombosis $[17,18]$. Cholette et al. reported an association between elevated C-reactive protein (CRP) levels and an increased postoperative thrombotic risk [19]. In this study, we were unable to analyze CRP levels, as it was not measured perioperatively in all patients. Instead, we concentrated on MPV being another factor associated with inflammation and thrombosis. Current advances in the quantification of laboratory markers of platelet function highlighted the role of platelets in a variety of thrombotic and inflammatory disorders. Larger platelets are functionally, metabolically and enzymatically more reactive, produce more thromboxane A2 and aggregate more readily in vitro. Accordingly, MPV has emerged as a relatively reliable marker of thrombosis and platelet function $[7,8,20,21]$. Evidence derived from retrospective and prospective studies suggest that high MPV level is a predictor of thrombotic events particularly in arterial disorders and is associated clinically with cardiovascular and cerebrovascular morbidity $[10,21,22]$. Moreover, some studies have focused on MPV in conditions related with venous thrombosis and demonstrated a strong independent association of high MPV with venous thromboembolism [23,24]. Although MPV has been regarded as a prognostic and predictive marker of both arterial and venous thrombosis, we did not find any association between perioperative MPV levels and early shunt occlusion in our study. There are some limitations to this study. First of all, study design was retrospective. Only 23 patients had shunt occlusion, which may be the reason for our incapability to reveal any statistically significant association between the variables and the occlusion rate. Moreover, shunt procedures were not always performed by the same surgeon. Different surgeons and their technical proficiency could also change the results. Lastly, hypercoagulation testing and/or aspirin resistance had not been done in all patients preoperatively. Therefore, we were unaware if there were any genetic predispositions to thrombosis in the occlusion group.

In conclusion, contrary to the studies demonstrating an association between high MPV levels and thrombosis, our study did not reveal such an association in patients who had undergone mBTS. To our knowledge, this is the only study questioning the role of MPV levels in shunt occlusion in patients with mBTS. Therefore, we believe further studies with larger populations are required to assess the potential predictive role of MPV levels in thrombotic shunt occlusion.

Acknowledgements:We thank Sevilay Karahan Ph. D. for assistance with statistical analysis, and for comments that greatly improved the manuscript

Declaration of Interests: There is no conflict of interest. We have not undergone any financial assistance for our research.

\section{References}

1. Bove EL, Kohman L, Sereika S, et al. The modified blalock-taussig shunt: Analysis of adequacy and duration of palliation. Circulation 1987;76:19-23.

2. Alkhulaifi AM, Lacour-Gayet $F$, Serraf A, Belli E, Planche C. Systemic pulmonary shunts in neonates: Early clinical outcome and choice of surgical approach. Ann Thorac Surg 2000;69:1499-1504.

3. Wells WJ, Yu RJ, Batra AS, Monforte H, Sintek C, Starnes VA. Obstruction in modified blalock shunts: A quantitative analysis with clinical correlation. The Ann Thorac Surg 2005;79:2072-2076.

4. Tsai KT, Chang CH, Lin PJ. Modified blalocktaussig shunt: Statistical analysis of potential factors influencing shunt outcome. J Thorac Cardiovasc Surg 1996:37:149-152.

5. Fermanis GG, Ekangaki AK, Salmon AP, et al. Twelve year experience with the modified blalock-taussig shunt in neonates. Eur J Cardiothorac Surg 1992;6:586-589.

6. Ahmad U, Fatimi SH, Naqvi I, et al. Modified blalocktaussig shunt: Immediate and short-term follow-up results in neonates. Heart Lung Circ 2008;17:54-58.

7. Bath PM, Butterworth RJ. Platelet size: Measurement, physiology and vascular disease. Blood Coagul Fibrinolysis 1996;7:157-161.

8. Colkesen $\mathrm{Y}$, Muderrisoglu $\mathrm{H}$. The role of mean platelet volume in predicting thrombotic events. Clin Chem Lab Med 2012;50:631-634.

9. Kilicli-Camur N, Demirtunc R, Konuralp C, Eskiser A, Basaran Y. Could mean platelet volume be a predictive marker for acute myocardial infarction? Med Sci Monit 2005;11:387-392.

10. Park Y, Schoene N, Harris W. Mean platelet volume as an indicator of platelet activation: Methodological issues. Platelets 2002;13:301-306.

11. Li JS, Yow E, Berezny KY et al. Clinical outcomes of palliative surgery including a systemic-to-pulmonary artery shunt in infants with cyanotic congenital heart disease: Does aspirin make a difference? Circulation 2007:116:293-297.

12. Gedicke M, Morgan G, Parry A, Martin R, Tulloh R. Risk factors for acute shunt blockage in children after modified blalock-taussig shunt operations. Heart Vessels 2010;25:405-409.

13. Al Jubair KA, Al Fagih MR, Al Jarallah AS et al. Results of 546 blalock-taussig shunts performed in 478 patients. Cardiol Young 1998;8:486-490. 
14. Guzzetta NA, Foster GS, Mruthinti N, Kilgore PD, Miller $\mathrm{BE}$, Kanter KR. In-hospital shunt occlusion in infants undergoing a modified blalock-taussig shunt. Ann Thorac Surg 2013;96:176-182.

15. Odim J, Portzky M, Zurakowski D, et al. Sternotomy approach for the modified blalock-taussig shunt. Circulation 1995;92:256-261.

16. Sahoo TK, Chauhan S, Sahu M, Bisoi A, Kiran U. Effects of hemodilution on outcome after modified blalock-taussig shunt operation in children with cyanotic congenital heart disease. J Cardiothorac Vasc Anesth 2007;21:179-183.

17. Eisenhardt SU, Habersberger J, Peter K. Monomeric c-reactive protein generation on activated platelets: The missing link between inflammation and atherothrombotic risk. Trends Cardiovasc Med 2009;19:232-237.

18. Tracy RP. Thrombin, inflammation, and cardiovascular disease: An epidemiologic perspective. Chest 2003;124:49-57.

19. Cholette JM, Rubenstein JS, Alfieris GM, et al. Elevated risk of thrombosis in neonates undergoing initial palliative cardiac surgery. The Ann Thorac Surg 2007;84:1320-1325.

20. Thompson CB, Jakubowski JA, Quinn PG, Deykin D, Valeri CR. Platelet size as a determinant of platelet function. J Lab Clin Med 1983;101:205-213.

21. Gasparyan AY, Ayvazyan L, Mikhailidis DP, Kitas GD. Mean platelet volume: A link between thrombosis and inflammation? Curr Pharm Des 2011;17:47-58.

22. Tsiara S, Elisaf M, Jagroop IA, Mikhailidis DP. Platelets as predictors of vascular risk: Is there a practical index of platelet activity? Clin Appl Thromb Hemost 2003;9:177-190.

23. Braekkan SK, Mathiesen EB, Njolstad I, Wilsgaard T, Stormer J, Hansen JB. Mean platelet volume is a risk factor for venous thromboembolism: The tromso study, tromso, norway. J Thromb Haemost 2010;8:157-162.

24. Paramo JA, Rocha E. Deep vein thrombosis and related platelet changes after total hip replacement. Haemostasis 1985;15:389-394. 